\title{
The value of biodiversity
}

\author{
Alho, CJR.* \\ Pós-graduação em Meio Ambiente e Desenvolvimento Regional, \\ Universidade para o Desenvolvimento do Estado e da Região do Pantanal - UNIDERP, \\ Rua Ceará 333, CEP 79003-010, Campo Grande, MS, Brazil \\ *e-mail: alho@unb.br \\ Received April 15, 2008 - Accepted April 15, 2008 - Distributed November 30, 2008
}

\begin{abstract}
In addition to its intrinsic value (nature working as it is; species are the product of a long history of continuing evolution by means of ecological processes, and so they have the right to continued existence), biodiversity also plays a fundamental role as ecosystem services in the maintenance of natural ecological processes. The economic or utilitarian values of biodiversity rely upon the dependence of man on biodiversity; products that nature can provide: wood, food, fibers to make paper, resins, chemical organic products, genes as well as knowledge for biotechnology, including medicine and cosmetic sub-products. It also encompasses ecosystem services, such as climate regulation, reproductive and feeding habitats for commercial fish, some organisms that can create soil fertility through complex cycles and interactions, such as earthworms, termites and bacteria, in addition to fungi responsible for cycling nutrients like nitrogen, phosphorus and sulfur and making them available to plant absorption. These services are the benefits that people indirectly receive from natural ecosystem functions (air quality maintenance, regional climate, water quality, nutrient cycling, reproductive habitats of commercial fish, etc.) with their related economic values.
\end{abstract}

Keywords: biodiversity value, conservation, fauna, flora, Pantanal.

\section{Valor da biodiversidade}

\section{Resumo}

Além do valor intrínseco da biodiversidade (a natureza funcionando como ela é; as espécies são o produto de longa história evolutiva continuada por meio de processos ecológicos e, desse modo, têm também direito à vida), a biodiversidade também desempenha papel fundamental como serviços do ecossistema, na manutenção de processos ecológicos. O valor econômico ou utilitário da biodiversidade se apóia na dependência do homem sobre a biodiversidade, produtos que a natureza supre: madeira, fibras, resinas, produtos químicos orgânicos, genes, assim como conhecimento para aplicação em biotecnologia, incluindo medicamentos e subprodutos cosméticos. Compreende também os serviços ecossistêmicos, tais como a regulação do clima, hábitats alimentares e reprodutivos para a pesca comercial, alguns organismos que contribuem para a fertilidade do solo por meio de ciclos interativos complexos, com a participação de organismos do solo (minhocas, cupins, bactérias, fungos) que atuam na ciclagem de nitrogênio, fósforo e enxofre, tornando-os disponíveis para serem absorvidos pelas plantas. Esses serviços são os benefícios que recebemos indiretamente da função dos ecossistemas naturais - manutenção da qualidade do ar, clima regional, qualidade de água, ciclagem de nutrientes, hábitats reprodutivos de peixes comerciais, com seus valores econômicos relacionados.

Palavras-chave: conservação, fauna, flora, Pantanal, valor da biodiversidade.

\section{Conceptual Range of Biodiversity}

The term biodiversity or biological diversity refers to the variety of life forms occurring in nature, as a result of evolutionary history. The concept includes the variety of organisms at all levels, from genetic variants belonging to the same species through arrays of different species; as well as the variety of ecosystems, encompassing ecological communities in a given habitat and the physical conditions under which they live (Wilson, 1992). It includes the present occurrence of different species of plants, animals and microorganisms, as well as the genes that different populations contain, and the ecosystems

composed from these associations of species and genes. This array of life forms is the result of a dynamic process of evolution throughout millions of years, from long before man appeared as a species on Earth. Since the appearance of man and especially in recent times, due to present environmental degradation, the role of human beings has been crucial in modifying ecological processes. Because of this dynamic evolution, some species have disappeared through extinction and ecosystems have become more complex, such as the Brazilian biomes. Thus, biodiversity increases when new genetic variation is pro- 
duced, a new species appears or an ecosystem increases in heterogeneous complexity. There is an intense interdependent relationship among the living forms of life in nature by means of ecological processes.

The concept of biodiversity considers three different levels of the natural system: 1) diversity of species (the variety of living forms); 2) genetic diversity (the variety of genetic information or codes contained in all distinct populations of plants, animals and microorganisms of the same species, such as differences between populations of the same species: for example, some primates living on the left bank of large Amazonian rivers differ genetically from those that live on the right bank; genetic diversity provides the basis of continuing adaptation to changing conditions); and 3) ecosystem diversity (the variety of habitats or different structural forms such as distinct phytophysiognomies occurring, for example, within the Cerrado or the Pantanal biomes.

Humans, as a biological species, are dependent on nature for a supply of oxygen for respiration and other forms of sustenance such as food and health, which depend on biological cycles and processes of the natural system. Although we rely upon natural live resources derived from biodiversity for our daily needs, the value of biodiversity provides us more indirectly with many other essential services, such as the hydrological cycle. For example, natural vegetation cover, mainly forest, acts in water catchments by regulating and stabilizing water runoff, buffering heavy rain and its effects such as extreme floods and droughts.

Recent studies, for example, "The Large-Scale Biosphere-Atmosphere Experiment in Amazonia -LBA" (LBA, 2008), an international research initiative conducted from 1995-2005 and led by Brazil, have shown the importance of the Amazonian forest for the global climate and regional rain process. The forest helps to maintain rainfall by recycling water vapor at a steady rate back into the atmosphere and through the forest canopy's effect in promoting atmosphere turbulence. The forest also provides numerous micro-climates or micro-habitats for a great number of specialized species which are dependent on such micro-climates for their occurrence, such as small frogs and many other forms of life.

Deforestation in the region has shown effects on erosion, water quality, loss of habitats for wildlife, degradation of aquatic habitats and loss of fishery, an increase in number of disease vectors (mosquitoes) and a surge of malaria cases in humans, as well as many environmental disruptions. Poor people are the first to suffer the effects of biodiversity degradation. Vegetation cover is an essential part of biodiversity; it is important for the maintenance of water and humidity levels and crucial for the maintenance of the oxygen/carbon dioxide balance in the atmosphere. The role of biodiversity in natural systems is intrinsically complex, and environmental degradation can affect many other components of the ecosystem, including the loss of species harvested for food by human beings. Biodiversity loss and degradation of natural hab- itats have led to disruption of ecosystem services, and consequently to economic costs and social losses.

Even though ecological processes and services are important, there are, in addition, moral, philosophical and political arguments that emphasize the value of biodiversity. Thus, biodiversity has an intrinsic value because it is part of the natural world, and the conservation of species, genetic resources and ecosystems is important for the maintenance of natural ecological processes. In addition, biodiversity performs a number of ecological services for us, which implies economic, aesthetic and recreational values, representing arguments of human interest or anthropocentric arguments.

\subsection{Intrinsic value}

Emphasizes the integrity of ecological communities, nature working as it is, as in representative portions of natural ecosystems preserved in protected areas, national parks, biological reserves and other categories of conservation units. These protected areas - managed by man, an important part of nature - emphasize the need to facilitate continued evolution of life forms in their natural habitats. There is an altruistic or non-humanistic value to support the intrinsic value of biodiversity: life forms should be conserved simply because they exist: they are the product of a long history of continuing evolution by means of ecological processes, and so they have the right to a continued existence. This ethical argument, stating that the protection of biological integrity is morally good, is based on the fact that most biodiversity loss nowadays is caused by human activities and disturbances, including, as a consequence, the recent extinction of species.

\subsection{Anthropocentric values}

Or economic or utilitarian values of biodiversity rely upon the dependence of man on biodiversity; products that nature can provide: wood, food, fibers to make paper, resins, chemical organic products, genes as well as knowledge. These economic benefits can be direct or indirect. Some benefits of biodiversity are represented in forms of goods that can be directly valued by the market. Extractive goods, such as the Brazil nut or ornamental fish, can be harvested in the forest and sold. Biodiversity is widely valued as a genetic storehouse for biotechnology, including medicine and cosmetic sub-products. Other biodiversity benefits are classified as indirect benefits, difficult to quantify in terms of market values, encompassing ecosystem services, such as climate regulation, reproductive and feeding habitats for commercial fish, and so on. Some organisms can create soil fertility through complex cycles and interactions, such as earthworms, termites and bacteria, in addition to fungi responsible for cycling nutrients like nitrogen, phosphorus and sulfur and making them available to plant absorption. Thus, ecosystem services are the benefits that people indirectly receive from natural ecosystems functions (air quality maintenance, regional climate, water quality, nu- 
trient cycling, reproductive habitats of commercial fish, etc.) with their related economic values.

\subsection{Aesthetic value}

This is expressed by humans seeking contact with nature, since natural and wild landscapes are aesthetically pleasing and provide opportunities to escape from large cities dominated by pollution and man-made landscapes. Ecotourism is an increasingly lucrative industry, be it bird watching in the Pantanal or floating among fish in Bonito.

In addition to protection of water resources, other ecosystem services are: soil formation and protection, nutrient storage and cycling, pollution breakdown and absorption, contribution to climate stability, maintenance of ecosystems and recovery from unpredictable events like severe floods and droughts.

\subsection{Mitigation and compensation values}

Conservation of biodiversity deals with many facets of human activities, including the environmental impacts resulting from the desire for socio-economic development, encompassing a change from a reactive stance in the protection of nature to a proactive attitude, in order to put development into the biological conservation framework, by means of applying measures to mitigate and compensate the impacts caused by man's occupation of new frontiers. Biodiversity and ecosystem services have different types of values, depending on human perception. Use-values are usually related to direct, indirect or optional use of biodiversity and its related services. Many costs associated with impacts on biodiversity and the level of related ecosystem services may take some time to become visible or may be apparent only at some geographical distance from where the impact or interference occurred.

\subsection{Market valuation}

There are different procedures to valuate the benefits generated by biodiversity in terms of market-based techniques. Usually market prices can be applied when direct benefits of biodiversity are involved: that is, when the consumer purchases the biodiversity-derived good. When biodiversity loss is involved, preventative or mitigatory expenditure is applied. If a given ecosystem is under threat from a human activity, for example, the cost of implementing a conservation unit, protecting the same ecosystem, may be used to estimate the benefit of that ecosystem's continued survival and representation. The idea is not strictly to estimate monetary value for biodiversity, but rather to provide alternatives to avoid loss. It is not always possible to be precise in these cases, since the value relies on mitigation/compensation. It is about finding an alternative to reduce the impact on biodiversity caused by human activity resulting from the drive towards economic development.

Biodiversity also has social amenity value. For example, considering the riverine fisherman, or a Brazil nut collector in the forest, biodiversity can improve their standards of living, making these forest people proud, and helping them lead more fulfilled lives. Biodiversity reinforces economic and social security; economic and social values will in turn reinforce biodiversity conservation by means of cultural instruments. On the one hand the value of provisioning services manifests itself through market prices; on the other, the importance of biodiversity as part of the ecosystem that produces and regulates cultural services cannot be captured in financial markets.

There is a sharp difference between private and social values of conserving biodiversity and ecosystem services. Consider for example the soybean plantation in central Brazil. This activity will usually ignore the external benefits of conservation that accrue to society in general. The planters will pursue the maximum benefits from intensive land use practices with subsequent biodiversity loss caused by drastic conversion of natural vegetation, leaching of excess nutrients and use of pesticides/herbicides, destruction of gallery forest, ignoring the legislation for land use, decreasing water quality and so on. Consequently, private decision-makers focus only on commercial agricultural productivity, without any commitment to valuing the broader social benefits of conservation, or to valuing biodiversity for its indirect importance for society.

\subsection{Political value}

Biodiversity loss in terms of species, genes and ecosystems taking place today is threatening the concept of sustained use of biological resources, and so it is undermining progress toward a sustainable society. There is a clear gap between the human desire for economic progress and nature's carrying capacity for biological exploitation and degradation. Biodiversity is also politically and strategically important for us since Brazil harbors about $30 \%$ of the world's forest and Amazonia is recognized as the largest continuous expanse of tropical forest on Earth, with one-third of the species known by Science, which is a small fraction of its enormous biological diversity waiting to be revealed by further research.

The Convention on Biological Diversity (CBD) was signed by 150 government leaders at the 1992 Earth Summit, which took place in Rio de Janeiro. The CBD currently includes 188 country-members or parties. The commitment is to look for sustainable use of biological resources, recognizing that biodiversity is more than plants, animals and microorganisms and their ecosystems. It also recognizes the human need for food security, medicines, fresh air and water, shelter, and a clean and healthy environment in which to live.

Brazil is one of the signatories of the CBD and organized the Eighth Meeting of the Parties to the Convention on Biological Diversity, in Curitiba, March 2006. The country has created programs in the Ministry of the Environment and the Ministry of Science and Technology to implement the commitments to biological 
conservation. The conflict that still exists between prioritizing economic and social development programs and prioritizing practical measures to protect biodiversity tends to favor the former, but some progress has been made in overcoming this difficulty. Some Convention recommendations have been achieved by means of implementation of specific programs such as "Diretrizes e Prioridades do Plano de Ação Para Implementação da Política Nacional da Biodiversidade" [Guidelines and Priorities for the Action Plan to Implement the National Policy for Biodiversity] (MMA, 2006).

The CBD recommends that parties must cooperate with one another to achieve conservation and sustainable use of biodiversity. International cooperation has been an important instrument to support programs in Brazil. The Global Environment Facility, supported by the seven largest industrial economies (Canada, France, Germany, Italy, Japan, United Kingdom and United States - G-7) has played a key role in financing programs to enable developing and mega-diverse countries, such as Brazil, to implement the CBD, the principal mechanism for advancing the conservation of biodiversity. The GEF has emphasized the importance, value and benefits of biodiversity. It has recognized the need for capacity building, technology transfer and sharing of knowledge to enable developing countries to implement the CBD.

\subsection{Scientific value}

The risk of biodiversity loss is evident if we continue to experience the current trend for predatory and unregulated exploitation of living natural resources. Biodiversity has value for Science, and this value transcends merely subjective arguments. Brazil has a significant importance in biodiversity conservation due to the magnitude of its biological diversity. The Pantanal is a wetland system with a variety of ecosystems due to the seasonal flooding, and is recognized as one of the most important biodiversity biomes (Alho and Gonçalves, 2005). Science is the instrument to accomplish the task of finding and understanding the forces that govern biodiversity structure and functions.

It is well recognized that Brazil is important in the scientific value of biodiversity because of the size of its territory, the diversity of its biomes, the size of its river system, the concept of a megadiverse country, and the biodiversity hotspots identified, with a large and continuous continental biota. The estimated size of known or recorded Brazilian biota is around 200,000 species, representing about $10 \%$ of the world's known number of species. These numbers may increase dramatically considering that the Neotropics constitutes, so far, one of the least studied regions. There are over 55,000 species of flora (without fungi species), representing nearly $20 \%$ of the world's flora. Brazilian biomes hold an immense number of terrestrial invertebrates, including 26,000 Lepidoptera, 12,000 Hymenoptera, 30,000 Coleoptera and so on. The number of amphibians (765 species) makes the country a leader in this taxon's diversity. Reptiles comprise
600 species, including 350 species of snakes. With about 1,500 species, Brazilian birds comprise one of the richest avifauna in the world. Our mammalian fauna, with about 530 recorded species, is also one of the most diverse in the world. The number of fish species reaches 3,000. Because of this, our need for conservation efforts is critical (Lewinshon and Prado, 2006).

The scientific value of biodiversity is relevant because our self-interest in biological resources supports economic and social benefits, such as wood, pharmaceuticals, cosmetics, and ecosystems services. It implies a potential value, our need for portions of the biodiversity about which we still do not know, which may be unpredictable. Our lack of scientific knowledge leaves an enormous gap between the current realized values of biodiversity and its potential future value. This gap is particularly wide for the new field of biotechnology for food, medicines, cosmetics, ornamental fish and plants, and other culturally and ecologically important fields. For example, a high percentage of all existing drugs on the market are derived from biodiversity. However, there are political concerns and conflicts of interest in bioprospecting, including the argument that local people will not receive a sufficient portion of the profits from drugs or cosmetics (or any genetic resource) developed from biodiversity found within their traditional area of cultural occupation.

The present trend in biodiversity loss threatens our opportunities for biotechnology, wood, medicines, energy, water supply, climate quality, with interference in essential ecological functions, all representing important values for human society.

Scientific studies on biodiversity are critical elements in achieving the recommendations of the $\mathrm{CBD}$, particularly concerning the knowledge and magnitude of biodiversity, scientific collections for taxonomic reference, species distribution, endemism and biogeography trends and patterns, ecosystem functions, endangered species and critical habitats, conservation practices, and many other relevant topics. The scientific value of biodiversity motivates a great potential and challenge for increasing knowledge and scientific investigation in Ecology, ranging from basic biodiversity inventories to intellectual instruments needed to generate technological innovations in Biotechnology.

\section{References}

ALHO, CJR. and GONÇALVES, HC., 2005. Biodiversidade do Pantanal. Ecologia e Conservação. Campo Grande: Editora UNIDERP. 142 p. ISBN: 858739294-8.

LBA - Large Scale Biosphere-Atmosphere Experiment in Amazonia, 2008. [abril/2008]. Available from: <http://lba.cptec.inpe.br/ $\mathrm{lba} /$ ?lg=eng $>$

LEWINSHON, TM and PRADO, PI., 2006. How many species are there in Brazil? Conservation Biology, vol. 19, no. 3, p. 619-624

MMA - Ministério do Meio Ambiente, 2006. Diretrizes e Prioridades do Plano de Ação para Implantação da Política Nacional da Biodiversidade. Biodiversidade 22. Brasília: MMA. 80 p.

WILSON, EO., 1992. The Diversity of Life. New York: W.W.Norton \& Company. $424 \mathrm{p}$. 